\title{
MANAJEMEN FASILITAS PARKIR DI MASJID Al-FALAH SURABAYA
}

\author{
Mauludi $^{*}$, Abdul Wadud ${ }^{1}$, Airlangga Bramayudha ${ }^{2}$

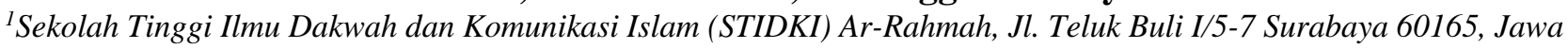 \\ Timur \\ ${ }^{2}$ Fakultas Dakwah dan Komunikasi, Universitas Islam Negeri Sunan Ampel, Jl. Ahmad Yani No.23 Surabaya 60231, \\ Jawa Timur \\ *e-mail:mauludi@stidkiarrahmah.ac.id
}

\begin{abstract}
The purpose of this study is to describe the management of parking facilities at mosque. This study used qualitative methods. The mosque that is the object of research is the Al-Falah Mosque. The process of collecting data is done by observation, in-depth interviews, and documentation. This study describes managerial supervision of parking facilities at Al-Falah Mosque. The Al Falah Mosque takmir committee collaborates with the Surabaya City Transportation Agency (DISHUB), residents who have vacant land and parking attendants from residents around the Al Falah Mosque. Managerial oversight of the parking area of the Al Falah Mosque is carried out with a coordinator system of permanent employees and financial reports from the security coordinator for the finance department. Suggestions for improvement, Al Falah Mosque should have a written system starting from Standard Operating Procedure (SOP) for land use, parking management and cooperation system.
\end{abstract}

Keywords: Management, mosque, parking

\begin{abstract}
ABSTRAK
Tujuan dari penelitian ini adalah untuk mendeskripsikan tentang pengelolaan fasilitas parkir pada tempat ibadah. Dalam Penelitian ini menggunakan metode kualitatif. Tempat ibadah yang menjadi objek penelitian ialah Masjid Al-Falah. Proses pengambilan data dilakukan dengan observasi, wawancara mendalam, dan dokumentasi. Penelitian ini menggambarkan tentang pengawasan secara manajerial fasilitas parkir di Masjid Al-Falah. Pengurus takmir Masjid Al Falah bekerjasama dengan dinas perhubungan (DISHUB) kota Surabaya, warga yang mempunyai lahan kosong serta petugas parkir dari warga sekitar Masjid Al Falah. Pengawasan secara manajerial terhadap pengelolaan parkir Masjid Al Falah dilakukan dengan sistem satu koordinator dari karyawan tetap dan laporan keuangan dari koordinator keamanan untuk bagian keuangan. Saran untuk perbaikan, seharusnya Masjid Al Falah mempunyai sistem yang tertulis mulai dari Standar Operasional Prosedur (SOP) penggunaan lahan, pengelolaan parkir dan sistem kerjasamanya.
\end{abstract}

Kata kunci: Manajemen, masjid, parkir

\section{PENDAHULUAN}

Banyak orang tidak mengindahkan solusi Islami, bahkan mengabaikannya hanya karena solusi yang ditawarkan berangkat dari nilai-nilai agama dan wahyu. Alasan ini mereka jadikan pembenaran untuk mengabaikan agama. Menurut mereka, kita sekarang hidup di era sains, bukan lagi era agama. Agama telah menyelesaikan tugasnya, dan dia tidak lagi mempunyai ruang dalam percaturan kehidupan modern. Salah satu dampaknya masyarakat kurang peduli dalam memakmurkan masjid. Dan mengelolanya dengan maksimal. ${ }^{1}$

\footnotetext{
${ }^{1}$ Nugroho. A. 2018. Studi Metode Dakwah Ceramah persuasif yang Digunakan Ustadz Jamil di Masjid At-Tauhid Betiting Surabaya Pada Pengajian Kiab Al-Wajiz fi Fiqh Sunnah. Masjiduna: Jurnal Ilmiah Stidki Ar-Rahmah.Vol 1 (1) : 116.
} 
Masjid bagi umat Islam mempunyai arti yang sangat luas dalam kehidupan, baik makna dalam konteks fisik (bangunan) maupun konteks spiritual. Kata masjid itu sendiri di ambil dari asal kata sajada-yasjudu-sujudan-masjidan yang berarti tempat sujud. Adapun dalam Al-Qur'an, kata masjid telah diulang sebanyak dua puluh delapan kali. Kata masjid juga banyak disinggung dalam Al-Qur'an dan Al-Hadist. Berdasarkan QS. An-Nur (24) : 36-37 dan dalam QS. At-Taubah (9):18 dapat disimpulkan bahwasanya masjid adalah rumah Allah dan umat-Nya disarankan untuk berdzikir (mengingat), mensyukuri atas semua nikmat Allah yang telah diberikan dan menyembah Allah dengan khusyu' serta memakmurkannya. ${ }^{2}$

Berdasarkan dari pengertian di atas, masjid lebih berperan dalam hal-hal yang berhubungan dengan Sang Pencipta alam semesta. Peran spiritualnya lebih menonjol dari pada peran masjid dalam hal fisiknya. Dari berbagai kejadian dan pengalaman yang terus berlangsung sehingga bisa dikatakan bahwa masjid mempunyai peran sebagai pusat kegiatan umat Islam, baik dalam kegiatan sosial, pendidikan, politik, budaya, dakwah maupun kegiatan ekonomi. Sehingga umat Islam berbondongbondong mendatangi masjid. ${ }^{3}$

Dalam ruang lingkup masjid, kekhusyukan adalah suatu kebutuhan primer yang harus terpenuhi. Kekhusyukan akan terpenuhi dengan beberapa cara, salah satu caranya yaitu dengan adanya jaminan keamanan. Dari hasil wawancara yang telah dilakukan kepada beberapa jamaah menyatakan demikian. Akan tetapi banyak masjid yang kurang memperhatikan masalah ini, terutama pada keamanan. Kebutuhan keamanan ini bisa didapatkan melalui tersedianya tempat parkir untuk kendaraan para jamaah. Akan tetapi, banyak masjid yang tidak mempunyai lahan parkir yang memadai sesuai dengan kapasitas kendaraan jamaah, walaupun ada sebagian masjid yang mempunyai lahan parkir yang memadai sesuai dengan kapasitas kendaraan jamaah, tetapi banyak di antaranya tidak dikelola dengan manajemen yang bagus.

Untuk aspek manajemen riayah, para pengurus berupaya untuk memelihara, menjaga dan mengembangkan fisik dan fasilitas masjid, termasuk menjaga keamanan dan kenyamanan masjid. Seperti misalnya, menjaga kebersihan masjid, dan menjaga keamanan jamaah, baik lahir maupun batin. Dengan ketiga aspek itu, maka fungsi dan aktifitas masjid diharapkan dapat berjalan dengan baik.

Salah satu masjid di Surabaya yang mengelola lahan parkir bagi para jamaah sholat adalah masjid Al-Falah. Masjid Al-Falah didirikan pada awal bulan suci Ramadhan 1393 H bertepatan dengan tanggal 27 September 1973 M. Masjid ini terletak di Jl. Raya Darmo 137A Surabaya di atas Taman Mayangkara seluas $3.206 \mathrm{~m}^{2}$ dengan kapasitas jama'ah mencapai 4.500 orang. ${ }^{4}$ Masjid ini sangat strategis, karena terletak pada pusat kota dan terletak di simpang lima antara J1. Raya Darmo dengan Jl. Raya Diponegoro. Tidak hanya itu, masjid ini juga terletak dekat dengan pusat keramaian seperti Kebun Binatang Surabaya, Taman Bungkul, perkantoran dan pertokoan. Akan tetapi, masjid ini tidak memiliki lahan parkir yang sesuai dengan kapasitas dari kendaraan jamaah Masjid Al-Falah. Masjid ini hanya memanfaatkan lahan yang seadaanya dan ditambah dengan lahan bahu jalan yang digunakan untuk area parkir. Akan tetapi, dengan lahan yang sangat minim ini Masjid Al-Falah bisa menjadikan fasilitas parkir sebagai sumber untuk memenuhi rasa aman bagi jamaah dan salah satu pemasukan untuk masjid.

\footnotetext{
${ }^{2}$ Tim FOKKUS BABINROHIS pusat \& ICMI Orsat Cempaka Putih \& Yayasan Kado Anak Muslim, "Pedoman Manajemen Masjid", hal 5.

${ }^{3}$ Tim FOKKUS BABINROHIS pusat \& ICMI Orsat Cempaka Putih \& Yayasan Kado Anak Muslim, "Pedoman Manajemen Masjid", hal 10

${ }^{4}$ Tim Yayasan Masjid Al-Falah, “35 Tahun Yayasan Masjid Al-Falah Surabaya”, 76. Hal 49-60.
} 
Atas dasar latar belakang apa yang sudah di paparkan di atas, sehingga peneliti tertarik untuk mengetahui konsep manajemen. Oleh karena itu tujuan peneliti untuk mendeskripsikan tentang pengelolaan fasilitas parkir di Masjid Al-Falah dan untuk menggambarkan pengawasan secara manajerial fasilitas parkir di Masjid Al-Falah.

\section{METODE PENELITIAN}

Penelitian ini menggunakan pendekatan kualitatif. Dalam peneliatian kualitatif peneliti sebagai instrumen kunci. Teknik pengumpulan datanya dilakukan secara triangulasi (gabungan), analisis datanya bersifat induktif atau kualitatif dan hasil penelitian kualitatif lebih menekankan makna dari pada generalisasi. ${ }^{5}$

Dalam penelitian ini, peneliti mengunakan metode kualitatif deskriptif. Metode kualitatif deskriptif adalah suatu metode yang digunakan untuk menemukan pengetahuan terhadap subjeksubjek pada penelitian tertentu. Penelitian kualitatif deskriptif berusaha untuk mendeskripsikan seluruh gejala atau keadaan yang ada, yaitu gejala atau keadaan menurut apa adanya yang terjadi pada saat penelitian dilakukan. ${ }^{6}$

Objek penelitian ini adalah manajemen pengelolaan fasilitas parkir Masjid Al-Falah. Adapun lokasi yang dijadikan objek penelitian yakni di Jalan Raya Darmo No. 137A Surabaya. Sedangkan proses pengambilan data dilakukan dengan Observasi, wawancara mendalam, dan dokumentasi.

Mekanisme observasi yang peneliti lakukan menggunakan observasi partisipatif. Dalam hal ini peneliti melakukan pengamatan dan pencatatan langsung secara sistematis terhadap fenomena yang ditemui pada fasilitas parkir di Masjid Al-Falah Surabaya. Hal ini bertujuan untuk mendukung hasil penelitian. Dalam teknik observasi peneliti bisa terlibat langsung dalam kegiatan sehari-hari dalam proses pengelolaan parkir sehingga bisa dijadikan sumber data. Selain sebagai pengamatan, peneliti juga ikut apa yang dikerjakan oleh sumber data dan ikut serta secara emosional bagaimana petugas menjalankan tugasnya. Oleh karena itu, teknik observasi ini diharapkan dapat memperoleh data yang lebih akurat dan lengkap.

Dalam kegiatan wawancara secara mendalam, peneliti mewawancarai Ketua Takmir, Koordinator Keamanan, petugas parkir, dan beberapa dari jama'ah Masjid Al-Falah. Untuk memperoleh informasi yang dibutuhkan diajukan seperangkat pertanyaan atau pernyataan yang tersusun dalam suatu daftar. ${ }^{7}$ Setelah peneliti melakukan wawancara dan mendapatkan jawaban dari informan dengan cara merekamnya, maka peneliti kemudian membuat transkrip dari hasil wawancara tersebut agar peneliti mendapatkan data langsung dari narasumber secara jelas dan terperinci.

Analisis data dilakukan dengan model Miles dan Huberman setelah pengumpulan data dilakukan dengan lengkap. Saat wawancara, peneliti sudah melakukan analisis terhadap jawaban informan yang telah diwawancarai. Apabila data yang didapat saat melakukan wawancara belum memuaskan, maka peneliti akan melanjutkan pertanyaan lagi sampai tahap tertentu sehingga diperoleh data yang dianggap kredibel.

\section{HASIL DAN PEMBAHASAN}

\section{Gambaran Umum Objek Penelitian}

\footnotetext{
${ }^{5}$ Sugiyono, “Metode Penelitian” (Bandung: ALFABETA, 2018), hal 8-9.

${ }^{6}$ Mukhtar, "Metode Praktis Penelitian Deskriptif Kualitatif”' (Jakarta Selatan : REFERENSI (GP Press Group), 2013) hal 10-11.

${ }^{7}$ Mukhtar, "Metode Praktis Penelitian Deskriptif Kualitatif” (Jakarta selatan : REFERENSI (GP Press Group), 2013), hal 100-101.
} 
Masjid Al Falah terletak di pusat kota surabaya yang berada di Jalan Raya Darmo no 137A. Berada di dekat tempat-tempat keramaian seperti Kebun Binatang Surabaya, Taman Bungkul dan Terminal Purabaya. Secara geografis Masjid Al Falah terletak antara lain, sebelah utara berbatasan dengan jalan Mayangkara, sebelah selatan berbatasan dengan jalan Porong, sebelah timur berbatasan dengan jalan Citarum, sebelah barat berbatasan dengan jalan Raya Darmo.

Masjid Al-Falah berdiri pada awal bulan suci Ramadhan 1393 H bertepatan dengan tanggal 27 September 1973 M ditandai dengan dilakukannya shalat terawih yang pertama dan keesokan harinya dilakukan sholat jum'at yang pertama dengan khatib Prof. K.H.M. Syafi'I Abdulkarim . Masjid Al-Falah terletak di Jl. Raya Darmo 137A Surabaya diatas Taman Mayangkara seluas 3.206 m2 dengan kapasitas jama'ah mencapai 4.500 orang.

Berdirinya Masjid Al-Falah Surabaya ini tidak dapat dipisahkan dengan keberadaan dari Yayasan Pendidikan Tinggi Dakwah Islam (PTDI) Jawa Timur, karena kedua-duanya merupakan suatu rangkaian usaha yang bertujuan untuk meningkatkan mutu iman dan ketakwaan umat islam di Jawa Timur, khususnya di Kota Surabaya, setelah terjadinya pemberontakan G30 S PKI. Berdiriya PTDI Jawa Timur dimulai oleh kepengurusan yang didominasi perwira-perwira ABRI yaitu Drs.H Zarkasi Effendi, Brigjen. KKO Mohammad Anwar, Dr. H. Tarmidzi Tahir, Kolenel KKO Soemardi P, Brigjen. KKO.K. Soemardi, Mayor KKO Darhalimi, Letkol Polisi Abdullah Ma'ruf, A.M Fatwa (seorang sipil).

Selain sebagai tempat shalat wajib lima waktu , ceramah-ceramah maupun pengajian Masjid Al-Falah juga menampung keinginan yang berkembang dikalangan jama'ah seperti: sebagai tempat berlangsungnya upacara nikah, sebagai tempat untuk orang yang ingin memeluk agama Islam sekaligus bimbingannya, sebagai tempat pelepasan jama'ah haji dan umrah dan sebagai tempat melaksanakan shalat jenazah.

Dengan kapasitas jama'ah mencapai 4.500 jamaah. Masjid Al-Falah dibagi menjadi 10 ruangan dan 8 ruangan di gunakan untuk sholat berjamaah. Untuk kepentingan parajamaah, disediakan pula tempat sandal/sepatu sebanya 572 kotak. Akan tetapi kotak-kotak tersebut tidak di gunakan lagi dan diganti denga petugas penjaga barang jamaah yang mencukupi kebutuhan jamaah. ${ }^{8}$

Susunan pengurus dan struktur Masjid Al-Falah Surabaya.

1. Ketua: Dwi Andi Handaya Rusman

2. Wakil Ketua I Bidang Dakwah \& Organisasi: Salahuddin Hanafi

3. Wakil Ketua II Bidang Rumah Tangga: Saukat Ali Zainuddin

4. Sekretariat: Lia

5. Muslimah: Ibu Sariah Usman

6. Bksf \& Ta'aruf: Lia, Endah, Nuryati, Noviana, Risma

7. Pelayanan Doa Dan Jenazah: Endang, Rahmawati

8. Pembinaan Pranikah atau Nikah: Lia, Nila

9. Kajian: Asyrofi

Sedangkan untuk program kegiatan yang ada pada Masjid Al-Falah yaitu Kursus membaca Al-Qur'an, Latihan menulis bahasa, Kursus tahsin Al-Quran (tartil, tahfidz, tafsir), Mengkaji shalat dan hukum Islam, Kajian(rutinan, mingguan, dan bulanan), Mengadakan jalan sehat bersama masyarakat sekitar, Mengadakan kajian muslimah, Pembinaan muallaf, Mengadakan kajian pranikah.

\footnotetext{
${ }^{8}$ Tim Yayasan Masjid Al-Falah, 35 Tahun Yayasan Masjid Al-Falah Surabaya (Surabaya: Yayasan Masjid Al Falah, 2008) Hal 49-59
} 


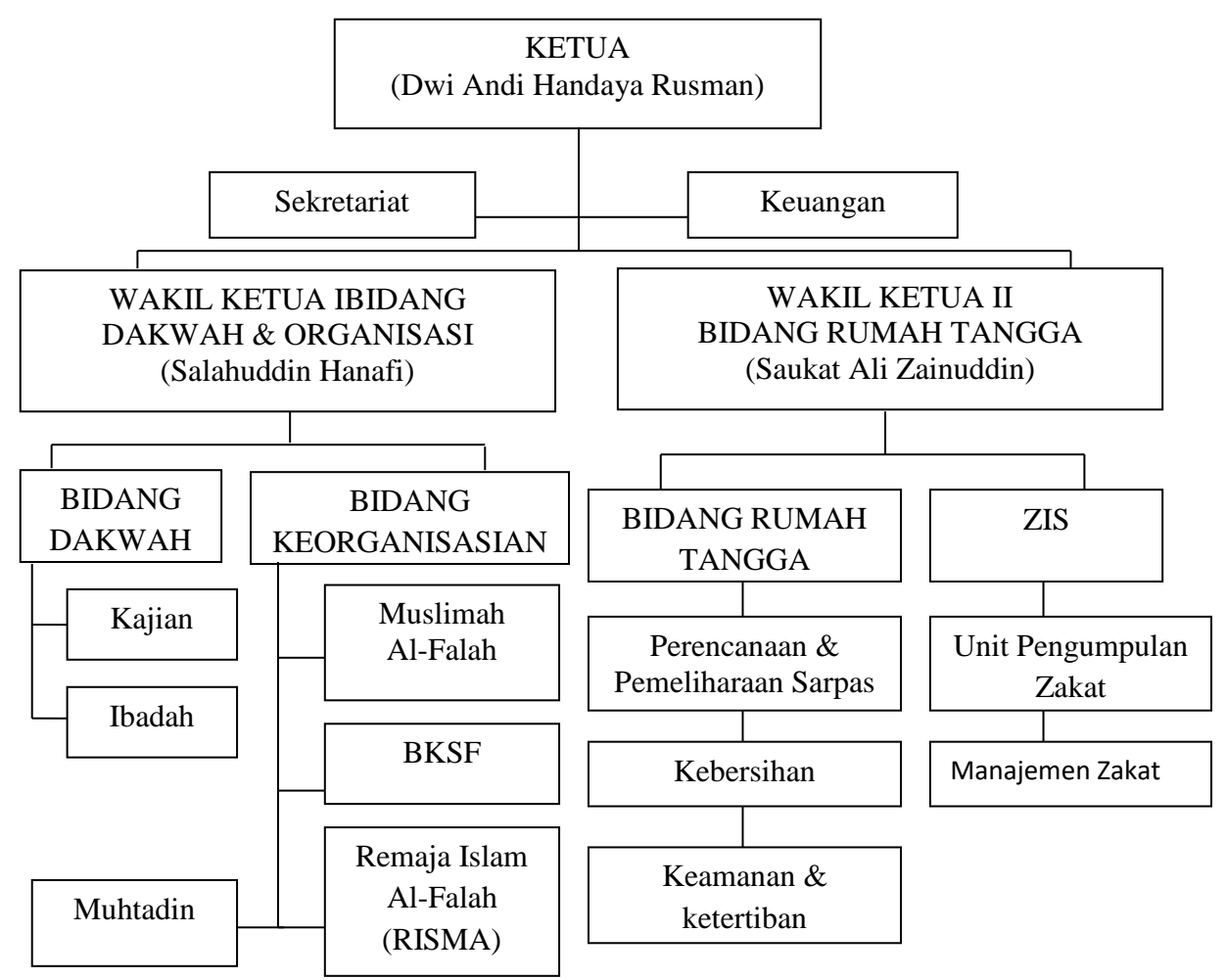

Gambar 1. Struktur organisasi Masjid Al Falah Surabaya

\section{Analisa Pembahasan}

Hasil temuan di lapangan, peneliti menyajikan data dari berbagai sumber, di antaranya merupakan data wawancara yang didapatkan dari beberapa informan yang mengetahui data-data yang dibutuhkan oleh peneliti, data dokumentasi yang peneliti dapatkan dari pengurus Masjid Al falah dan data dari hasil observasi yang dilakukan oleh peneliti selama jadwal penelitian berlangsung.

Data yang telah didapatkan peneliti kemudian peneliti sajikan dalam bentuk deskripsi atau dipaparkan secara terperinci. Penyajian data ini dibagi menjadi beberapa unsur diantaranya Inventarisasi Aset, Legal Audit, Penilaian Aset, Optimalisasi Aset, Pengawasan serta Pengendalian.

Pertama Inventarisasi Aset, Dalam inventarisasi aset yang dilakukan oleh Masjid Al Falah sebagai mana yang telah peneliti kutip dari wawacara yang peneliti lakukan dengan pak Andi selaku ketua takmir Masjid Al Falah mengatakan bahwa:

"Lokasinya dari sisi selatan, sisi depan, sampai sisi samping utara. Kalau di sebelah utara itu hanya bagian timur masjid. Karena sebelah utara bagian barat itu wilayah sekolah SD Al Falah, kalau di pertigaan sebelah utara itu sudah masuk area sekolah. karena itu wilayah sekolah maka wilayah parkir Masjid Al Falah yaitu mulai dari sebelah selatan sampai ke sisi sebelah timur masjid."

Sedangkan Menurut Pak Sugeng BR selaku koordinator keamanan Masjid Al Falah mengatakan bahwa didalam wawancara dengan peneliti mengatakan bahwa:

"Mobilnya ada tiga tempat, utara, tengah dan selatan. Yang selatan terbagi menjadi tiga Ssebelah timur dibagi menjadi tiga Shift, dan sebelah utara dibagi menjadi dua Shift."

Menurut pak Sholahuddin selaku wakil ketua takmir Masjid Al Falah pada wawancara dengan peneliti mengatakan bahwa:

"Karena menggunakan banyak fasilitas-fasilitas pemkot, kalau pada hari jum'at, parkir itu sebagian ada disisi barat yang ada di jalan raya darmo, di jalan Darmo terdapat 3 sisi, 2 sisi dipakai untuk 
parkir, akan tetapi setelah jum'at secepatnya harus bersih semua dari kendaraan yang parkir. Dan disekitar-sekitar masjid, terdapat pada jalan Porong dan jalan Mayangkara”

Sedangkan untuk volume kendaraan di parkir Masjid Al Falah waktu hari aktif menurut pak Sugeng BR selaku koordinator keamanan didalam wawancara dengan peneliti mengatakan:

"untuk sepeda motor sekitar 100 dan mobil sekitar 75"

Adapun pada hari jum'at pak Sugeng BR mengatakan sebagai mana terdapat bahwa: “iya semuanya orang luar, hari jum 'at untuk sepeda motor kurang lebih 500-600”

Adapun pada hari ketika ada acara tabligh akbar pak Sugeng BR mengatakan bahwa: "kalau semua sepeda motor jumlahnya kurang lebih 500. Jumlah mobilnya antara 50-60"

Sedangkan ukuran keseluruhan dari luas lahan yang di gunakan untuk tempat parkir Masjid Al Falah menurut pak Sugeng BR mengatakan:

"4x50 $M^{2}$ untuk yang seputaran sini dan yang di luar $4 \times 100 \mathrm{M}^{2}$ "

Adapun batas penggunaan lahan parkir Masjid Al Falah sesuai yang di katakan oleh pak Sugeng BR yang terdapat pada wawancara dengan peneliti pada poin J138 adalah:

"Belum ada prosedur yang jelas, kemarin sebenarnya pihak pemkot itu susah, karena tempat ini masjid akan tetapi ditarik, lalu akhirnya pemkot mengambil keputusan yang istilahnya sebagai tanda bukti bahwa masjid ada kontribusi untuk menambah kas daerah, tidak peduli jumlahnya berapapun, yang terpenting ada bukti setor. kalau jangka waktu penggunaannya tidak ada, tergantung bagaimana kebijakan pemkot berikutnya"

Inventarisasi aset terdiri dari dua aspek, yaitu inventarisasi fisik dan legal/yuridis. Aspek fisik terdiri atas bentuk, volume, luas, lokasi, jenis, alamat dan lain-lain. Sedangkan aspek yuridis/legal adalah status penguasaan, masalah legal yang dimiliki, batas akhir penguasaan dan lain-lain. Proses kerja yang dilakukan adalah pendataan, kondisifikasi, pengelompokan dan pembukuan/administrasi sesuai dengan tujuan manajemen aset. ${ }^{9}$

Dari data wawancara yang telah disampaikan oleh narasumber di atas dan ditambah dengan data hasil observasi, dapat peneliti simpulkan bahwa di bagian sebelah barat Masjid Al Falah adalah J1 Raya Darmo dengan menggunakan 1 jalur sebagai tempat parkir dan khusus di hari jum'at 2 jalur yang digunakan dengan ketentuan setelah sholat jum'at harus bersih dari kendaraan yang parkir. Tempat ini dikhususkan untuk tempat parkir mobil. Di bagian sebelah utara Masjid Al Falah yang bertempat di Jl Taman Mayangkara khusus untuk parkir mobil. Di bagian sebelah timur Masjid Al Falah yang bertempat di Jl Citarum khusus parkir motor dengan menggunakan trotoar dan jalan (pada waktu sholat jum'at) dan untuk waktu selain dari itu sebagian tempat digunakan untuk parkir motor. Di bagian timur Masjid Al Falah yang berada di sebelah selatan dan sebagian tempat digunakan untuk parkir mobil yang berada di bagian timur Masjid Al Falah sebelah utara. Di bagian sebelah selatan Masjid Al Falah yang bertempat di J1 Porong khusus untuk parkir motor (khusus hari jum'at) dan di hari-hari biasa khusus untuk tempat parkir mobil.

Volume kendaraan di parkir Masjid Al Falah waktu hari aktif senin-jum'at jumlah sepeda motor kurang lebih 100 dan mobil kurang lebih 75. Di hari jum'at sepeda motor kurang lebih 500600 dan mobil kurang lebih 200 Di hari ketika ada tabligh akbar sepeda motor kurang lebih 500 dan mobil 50-60.

Ukuran keseluruhan dari luas tempat yang digunakan untuk parkir Masjid Al Falah di jalan Raya Darmo kurang lebih 300 M dan di jalan Juwono kurang lebih 250 M dan di jalan Porong kurang

\footnotetext{
${ }^{9}$ Doli D. Siregar, manajemen aset (Jakarta : PT. Kresna Prima Persada, 2017), hal 517-520
} 
lebih 200 M dan di jalan Darmo Kali kurang lebih 100 M dan di jalan Taman Mayangkara 100 M dan di jalan Citarum 100 M. Lahan tersebut yang digunakan untuk parkir pada hari jum'at. Adapun untuk hari senin-sampai kamis lahan yang di gunakan yaitu di Jalan Raya Darmo $100 \mathrm{M}$ dan di jalan Taman Mayangkara $100 \mathrm{M}$ dan di jalan Porong kurang lebih $100 \mathrm{M}$ dan di jalan Citarum $100 \mathrm{M}$.

Adapun untuk batas pemakaian lahan yang digunakan sebagai tempat parkir Masjid Al Falah tidak ada ketentuan jangka waktu. Sehingga pemakaian lahan parkir tersebut hanya mengikuti peraturan-peraturan daerah yang ada. Jika peraturan daerah berubah maka pihak manajemen Masjid Al Falah mengikutinya.

Kedua, Legal Audit. Dalam legal audit mengenai aset yang di gunakan oleh Masjid Al Falah sebagaimana yang telah di sampaikan oleh beberapa pengurus takmir Masjid Al Falah. Menurut pak Andi selaku ketua takmir Masjid Al Falah dalam wawancara mengatakan bahwa:

"tempat yang di pakai untuk tempat parkir adalah jalan. Karena yang di pakai adalah jalan maka pengelolaannya diserahkan kepada dinas perhubungan dan masjid dengan sistem bagi hasil dan bekerjasama dengan pengelola setempat, nah kita itu pengelola. Nanti pihak parkir Masjid Al Falah harus setoran ke dinas berhubungan. Seperti itu pada umumnya."

Menurut Pak Sugeng BR selaku koordinator keamanan dari Masjid Al Falah dalam wawancara mengatakan bahwa:

"iya pagar besi itu adalah batas, kalau yang dulu, pak samsuri tidak boleh membangun bangunan disitu. Kenapa? Karena itu fasum bukan miliknya masjid. Akan tetapi seiring berjalannya waktu pada akhirnya orang-orang, setelah beliau meninggal, baru ada yang membangun, akan tetapi saya tidak tahu pertimbangannya bagaimana, mungkin karena ini masjid, sehingga tidak ada teguran."

Dalam wawancara yang lain Pak Sugeng BR mengatakan bahwa:

"warga yang berada di sebelah timur menyerahkan pengelolaannya kepada masjid. Dengan syarat tidak diperbolehkan untuk transaksi jual beli di area tersebut."

Menurut pak Sholahuddin selaku wakil ketua takmir Masjid Al Falah mengatakan bahwa: "Masjd Al Falah tempat parkirnya terbatas, tidak seperti masjid-masjid kebanyakan. Masjid Al Falah terletak pada pusat kota sehingga tempat parkir yang di gunakan adalah jalan.”

Dalam prosedur pengelolaan lokasi parkir Masji Al Falah sebagai mana yang di sampaikan oleh pak Sugeng selaku koordinator keamanan mengatakan:

"Pemkot belum membuat prosedur pengelolaan, karena ini adalah masjid sehingga tidak di tarik dan akhirnya pemkot mengambil keputusan atau istilahnya tanda bukti bahwa ada kontribusi untuk menambah kas daerah. Tidak peduli berapa jumlahnya akan tetapi yang terpenting adalah bukti setor. Adapun jangka waktu penggunaan lahan tidak ada, tergantung kebijakan pemkot berikutnya. Per bulan Masjid Al Falah setor Rp 1.100.000 ke Dinas Perhubungan. Aturan resmi dari Dinas Perhubungan seperti itu, yang di lapangan tau dibalik, kemarin waktu negosiasi beruntung orangnya enakan".

Adapun strategi yang digunakan Masjid Al Falah sebagai mana yang dikatakan oleh koordinator keamanan pak Sugeng mengatakan:

"Mungkin dulu ya uda digulirkan masjid mau di robohkan dibangun baseman untuk parkir jadi turun satu naik lima kalau ndak salah itu dan akhirnya gagal terkendala tanah”.

Legal audit merupakan satu lingkup kerja manajemen aset yang berupa inventarisasi status penguasaan aset, sistem dan prosedur penguasaan atau pengalihan aset, identifikasi dan mencari solusi atas permasalahan legal, dan strategi untuk memecahkan berbagai permasalahan legal yang terkait dengan penguasaan ataupun pengalihan aset. Permasalahan legal yang sering ditemui antara 
lain status hak penguasaan yang lemah, aset dikuasai pihak lain, pemindah tanganan aset yang tidak termonitor dan lain-lain. ${ }^{10}$

Dari berbagai narasumber diatas dapat peneliti simpulkan bahwasanya lahan yang digunakan sebagai tempat parkir oleh Masjid Al Falah yang pertama adalah lahan dengan kepemilikan pemerintahan, karena lokasi yang digunakan untuk parkir adalah bahu jalan serta jalan yang ada disekitar Masjid Al Falah. Bekerjasama dengan pemerintahan (dinas perhubungan) berdasarkan ketentuan yang telah disepakati bersama diantaranya adanya bukti pemasukan untuk kas dinas perhubungan dari Masjid Al Falah sebesar Rp 1.100.000. Kedua, tanah kepunyaan warga yang ada di sebelah timur Masjid Al Falah dengan prosedur perizinan dengan persyaratan tidak adanya transaksi jual beli di area tersebut.

Ketiga, Penilaian Aset. Dalam penilaian aset yang dilakukan oleh pengurus takmir Masjid Al Falah untuk menilai kinerja dari aset parkir Masjid Al Falah sebagaimana yang telah disampaikan oleh Pak Sugeng BR selaku koordinator keamanan Masjid Al Falah dalam wawancara mengatakan bahwa:

"Tidak ada, itu semua kembali kepada faktor insentifnya, sehingga insentifnya nanti pertiga bulan akan di itung, kalau memang dalam kurun tiga bulan itu terlampaui 15 juta, ada presentase buat petugas unntuk rehatnya. selama 3 bulan itu beberapa persen sumbangan yang masuk akan di total, katakan total dari sepeda berjumlah 18 juta, dari si A, si B dan si C ini dikumpulkan, berapa persen dari 18 juta itu. itu nanti dikalikan per tiga bulan, ya itu adalah uangnya."

Penilaian aset merupakan satu proses kerja untuk melakukan penilian atas aset yang dikuasai. Biasanya ini dikerjakan oleh konsultan penilaian yang independen. Hasil dari nilai tersebut akan dapat dimanfaatkan untuk mengetahui nilai kekayaan maupun informasi untuk penetapan harga bagi aset yang ingin dijual. ${ }^{11}$

Dari data yang didapat oleh peneliti melalui wawancara dengan narasumber di atas dapat peneliti simpulkan bahwasanya dalam keparkiran Masjid Al Falah dalam penilaian kinerjanya dengan adanya target capaian per tiga bulan. Ketika target terpenuhi maka ada apresiasi rehat untuk petugas.

Keempat, Optimalisasi Aset. Dalam upaya untuk optimalisasi aset, pengurus takmir Masjid Al Falah melakukan beberapa hal, baik itu hal-hal yang akan dilaksanakan dalam jangka pendek maupun untuk jangka panjang. Dalan hal ini sebagaimana yang telah di sampaikan oleh beberapa narasumber, menurut pak Andi selaku ketua takmir Masjid Al Falah di dalam wawancara mengatakan bahwa:

"tentang parkir? Tidak masalah, mengenai parkirini nanti dibantu juga dengan pak saukat. Kalau parkir di Masjid Al Falah ini menggunakan hanya satu koordinator saja yang dari karyawan Masjid Al Falah, yang mana kita juga berdayakan orang-orang dari luar. Dari luar itu ada parkir motor, parkir mobil dan nanti sitemnya semacam bagi hasil pendapatan parkir, ada sebagian untuk mereka ada sebagian untuk masjid. Hali tersebut diserahkan harian, sehingga terkumpul per bulan mendapatkan hasil berapa, seperti itu tentang parkir."

Menurut Pak Sugeng BR selaku koordinator keamanan dari Masjid Al Falah mengatakan bahwa:

"Jamaah di sarankan langsung meninggalkan kendaraannya, dari petugas akan mengatur tempatnya begitu pula ketika akan keluar, akan di siapkan motornya sesuai dengan ke arah mana jamaah akan pergi. Mobil ada tiga tempat, utara, timur dan selatan. Yang selatan ada tiga Shift dan yang timur

\footnotetext{
${ }^{10}$ Doli D. Siregar, manajemen aset (Jakarta : PT. Kresna Prima Persada, 2017), hal 517-520

${ }^{11}$ Doli D. Siregar, manajemen aset (Jakarta : PT. Kresna Prima Persada, 2017), hal 517-520
} 
ada dua Shift dan yang utara ada dua Shift. Kalau yang utara waktu pagi ada dua orang, yang malam ada tiga orang ditambah relawan dan yang timur waktu pagi ada dua orang, dan yang malam satu orang. Dibagian selatan waktu pagi ada dua orang, waktu siang satu orang dan waktu sore ada satu orang. Untuk petugas yang dibagian depan temponya sedikit lebih panjang, dari pukul 07:00 WIB sampai 16:00 WIB. dan pukul 16:00 WIB sampai waktu Isya."

Dalam wawancara yang lain Pak Sugeng BR mengatakan:

"Shiftnya antara pukul 07:00 WIB sampai 14:00 WIB dan pukul 14:00 WIB sampai 21:00 WIB untuk sepeda motor. Untuk mobil pukul 06:30 WIB sampai 16:00 WIB dan Pukul 16:00 WIB sampai 20:00 WIB. ada juga yang mulai pukul 07:00 WIB sampai 11:00 WIB dan pukul 11:00 WIB sampai 15:00 WIB dan pukul 15:00 WIB sampai 21:00 WIB. Kalau ada jamaah ingin sholat, tetap di persilahkan, adapun tarifnya tidak ada. Hari jum'at itu sebagai bentuk partisipasi petugas setor ke Masjid Al Falah sebesar Rp 225.000. total dari penitipan sandal dan pendapatan sepeda motor, yang sebagai petugas parkir adalah orang luar dengan jumlah yang banyak, sholat jum'at dan bulan Ramadhan seтua petugasnya adalah orang luar. Biasanya yang di terima oleh Masjid Al Falah total Rp 700.000-800.000. Mobil dan sepeda motor, untuk sepeda motor itu yang di dapat oleh petugas adalah sebesar Rp 35.000 di tambah uang makan sebesar Rp 10.000 total menjadi Rp 45.000. misal, ada kelebihan ketika jamaah membayar tarif parkir maka kelebihan dari tarif yang telah di tentukan adalah hak petugas. Contoh petugas di kasih jamaah Rp 5.000 berarti yang Rp 4.000 adalah untuk petugas. Tarif yang telah ditetapkan dari Masjid Al Falah untuk sepeda motor sebesar Rp 1000 untuk mobil Rp 2000. Karena pelayan masing-masing petugas ada yang berbeda, sehingga ada sebagian jamaah memberikan lebih. Jika jamaah memberikan lebih maka kelebihan itu untuk petugas parkir."

Menurut pak Sholahuddin selaku wakil ketua takmir Masjid Al Falah mengatakan bahwa: "apabila ada dua atau tiga mobil misalnya, ada perempuan dan ada laki-laki, yang harus diperioritaskan adalah ibu-ibu, itu paling penting. jadi ada yang spesial terutama untuk ibu-ibu yang kedua ialah saudara-saudara yang berkebutuhan khusus, terutama difabel, itu harus prioritas kalau perlu parkirnya turun di depan masjid. Dalam kesehariannya parkir itu dikelolah oleh tim keamanan Masjid Al Falah juga dibantu oleh warga dan ini sudah menjadi turun temurun warga sekitar. Artinya pengurus RT/RW yang ada disekitar masjid termasuk dan infaq parkir dalam hal ini ada semacam sharing sebesar 60\% untuk pemasukan Masjid Al Falah dan $40 \%$ diambil oleh pengurus warga sekitar Masjid Al Falah”.

Menurut mas Sugeng Selaku petugas parkir Masjid Al Falah mengatakan bahwa: "intinya petugas itu harus senyum, Sama petugas juga harus membantunya sesuai dengan kemampuannya, jangan sampai jamaah untuk memarkir kendaraan mereka mencari-cari tempat sendiri. Kalau keadaan tidak terlalu ramai"

Tabel 1. Daftar Nama Petugas Parkir Sepeda Motor

\begin{tabular}{ccccc}
\hline No & Pagi & Bagian & Sore & Bagian \\
\hline 1 & Agus & Selatan & Sugeng & Selatan \\
2 & Sman & Selatan & Munir & Selatan \\
3 & Saiful & Utara & Hayat & Selatan
\end{tabular}


Utara

Tabel 2. Daftar Nama Petugas Parkir Mobil

\begin{tabular}{ccccc}
\hline No & Pagi & Bagian & Sore & Bagian \\
\hline 1 & Riawan & Timur & Bonidin & Utara \\
2 & Hisyam & Utara & Matluki & Utara \\
3 & Adi & Utara & Somat & Timur \\
4 & Nur & Selatan & Yuli & Selatan \\
5 & Yudi & Selatan & & \\
& & & & \\
\hline
\end{tabular}

Optimalisasi aset merupakan proses kerja dalam manajemen aset yang bertujuan untuk mengoptimalkan potensi fisik, lokasi, nilai, jumlah/volume, legal dan ekonomi yang dimiliki aset tersebut. Dalam tahapan ini, aset -aset yang dimiliki diidentifikasi dan dikelompokkan menjadi dua kelompok, diantaranya adalah kelompok aset yang berpotensi dan aset yang tidak berpotensi. Aset yang berpotensi dikelompokkan berdasarkan sektor-sektor unggulan yang menjadi tumpuan dalam strategi pengembangan ekonomi nasional, baik dalam jangka pendek maupun jangka panjang. Tentunya kriteria untuk menentukan hal ini harus terukur dan transparan. Sedangkan aset yang tidak bisa dioptimalkan, harus dicari faktor-faktor penyebabnya. Apakah faktor permasalahan legal, fisik, nilai ekonomi yang rendah ataupun faktor yang lainnya. Kemudian hasil akhirnya dari tahapan ini adalah sebagai rekomendasi yang berupa sasaran, strategi dan program untuk mengoptimalkan aset yang dikuasai. ${ }^{12}$

Dari data yang telah di paparkan dari beberapa narasumber di atas dapat penelititi simpulkan bahwa sistem pengelolaan keparkiran di Masjid Al Falah Menggunakan sistem 1 koordinator dari karyawan Masjid Al Falah dan petugas-petugas yang berada di lapangan menggunakan Sumber Daya Manusia (SDM) yang berasal dari warga sekitar Masjid Al Falah dengan ketentuan-ketentuan yang telah disepakati bersama. Diantara kesepakatan yang telah disepakati yaitu warga dan pihak masjid menggunakan sistem bagi hasil dengan pembagian hasil yang didapatkan akan masuk ke masjid sejumlah $60 \%$ dan warga mendapatkan hasil sejumlah $40 \%$. Petugas dibagi menjadi dua bagian diantaranya yaitu bagian mobil dan bagian motor.

Mekanisme parkir Masjid Al Falah jadwal petugas parkir dibagi menjadi beberapa Shift, diantaranya: Shift pertama khusus motor mulai jam 07.00 s/d 14.00 WIB dan Shift kedua dimulai dari jam $14.00 \mathrm{~s} / \mathrm{d} 21.00 \mathrm{WIB}$. Adapun petugas parkir khusus motor dalam Shift pertama bejumlah empat orang dan di Shift kedua berjumlah empat orang.

Dalam jadwal petugas parkir Masjid Al Falah di bagi menjadi dua macam diantaranya: macam yang pertama yang berada disebelah utara dan timur, Shift pertama yang dimulai dari jam $06.30 \mathrm{~s} / \mathrm{d}$ 16.00 WIB dan Shift kedua dimulai dari 16.00 s/d 20.00 WIB. Macam yang kedua yang berada disebelah selatan, Shift pertama yag dimulai dari jam 07.00 s/d 11.00 WIB dan Shift kedua dimulai

\footnotetext{
${ }^{12}$ Doli D. Siregar, manajemen aset (Jakarta : PT. Kresna Prima Persada, 2017), hal 517-520
} 
dari jam 11.00 s/d 15.00 WIB dan Shift ketiga dimulai dari jam 15.00 s/d 21.00 WIB. Diatas jam tersebut tidak ada petugas parkir yang berjaga, sehingga tidak ada tarif parkir.

Petugas parkir khusus mobil dalam Shift pertama berada disebelah utara berjumlah dua orang dan Shift kedua berjumlah tiga orang ditambah relawan. Petugas parkir mobil Shift pertama sebelah timur dua orang dan Shift kedua berjumlah satu orang. Petugas parkir mobil sebelah selatan Shift pertama berjumlah dua orang dan Shift kedua berjumlah satu orang dan Shift yang ketiga berjumlah satu orang.

Adapun pelayanan yang diberikan oleh petugas parkir kepada pengguna tempat parkir yang ada di Masjid Al Falah sebagai berikut: Pertama memberikan senyuman kepada jamaah yang datang. Kedua, Jika pada hari tersebut ramai dan jamaah datang secara bersama-sama dengan membawa motor maka jamaah tersebut tidak perlu menata kendaraannya karena petugas akan menata dengan rapi kendaraan-kendaraan yang datang dan untuk jamaah yang membawa mobil petugas akan mengarahkan dimana tempat parkirnya. Ada juga jamaah jika keburu-buru dan belum mendapatkan tempat parkir mobil, maka jamaah akan menyerahkan kunci mobilnya dan mobil akan di parkirkan oleh petugas parkir. Ketiga, apabila hujan turun dan di atas kendaraan terdapat jaket atau barangbarang, maka petugas akan mengamankan jaket dan barang-barang tersebut agar tidak basah terkena hujan. Keempat, jika terdapat helm diatas kendaraan yang memungkinkan terkena air ketika hujan turun maka petugas akan menaruh helm tersebut sehingga tidak basah. Kelima, ketika jamaah telah selesai melakukan kegiatan di dalam masjid kemudian jamaah hendak pergi maka petugas akan menyiapkan kendaraan jamaah sesuai dengan arah yang akan dituju (khusus motor).

Tarif parkir Masjid Al Falah untuk kendaraan sepeda motor sebesar Rp 1.000 dan untuk kendaraan mobil Rp 3.000. Adapun jaminan keamanan dari keparkiran Masjid Al Falah adalah sebagai berikut: apabila dalam kehilangan itu memang murni kelalaian dari petugas parkir maka dari pihak Masjid Al Falah akan mengganti sesuai dengan kemampuan dari Masjid Al Falah.

Pada waktu sholat jum'at petugas parkir di serahkan kepada warga sekitar dan hasil dari tarif parkir diserahkan kepada warga semuanya, dengan ketentuan petugas tetap setor sebagai partisipasi untuk masjid sebesar Rp 225.000.

Kelima, Pengawasan dan Pengendalian. Dalam pengawasan dan pengendalian yang dilakukan oleh pengurus takmir Masjid Al Falah sebagaimana data yang telah didapatkan oleh peneliti. Menurut pak Andi selaku ketua takmir Masjid Al Falah mengatakan bahwa:

"pengawasannya seperti apa yang sudah disampaikan sebelumnya, ada satu orang namanya Pak Sugeng BR, dialah yang mengkoordinasi semuanya, jadi Pak Sugeng BR itu sebenarnya bagian keamanan Masjid Al Falah, hanya saja dia ditugaskan untuk mengkoordinasi bagian keparkiran. Mulai dari pengaturan petugasnya, jadwal jaga petugas parkir, pengawasan secara umum di lapangan, dan terkait juga ketertiban parkirnya. Semua itu langsung di tangani oleh koordinator keamanan. Kalau takmir masjid melihat, parkir Masjid Al Falah ini alhamdulillah cukup bagus. Waktu saya disini saya apresiasi tertib, parkirnya udah bagus, orang-orangnya cukup, ndak ada yang terbengkalai di bagian keparkiran ini."

Menurut Pak Sugeng BR selaku koordinator keamanan Masjid Al Falah mengatakan bahwa: "Setiap hari parkir ada laporan keuangan, yang ngelola langsung dari koordinator keamanan, setiap petugas mobil akan setor, jumlah setornya ada yang $R p 20.000$ ada yang $R p 10.000$ dan ada yang Rp 30.000 dan ada yang Rp 45.000. Apa? Untuk jadwal pelaporannya dua hari sekali pada hari senin, rabu dan jum 'at'. 
Tabel 3. Laporan Hasil Parkir Masjid Al Falah

\begin{tabular}{|c|c|c|c|}
\hline No & Kredit & Jumlah & \\
\hline 1 & Makan gilo & 60.000 & \\
\hline 2 & Tukang sapu & 15.000 & \\
\hline \multirow[t]{3}{*}{3} & Setor dishub & 75.000 & \\
\hline & Jumlah & 150.000 & \\
\hline & Honor & & \\
\hline 1 & Sugeng Br & 69.000 & \\
\hline 2 & Oga & 40.000 & \\
\hline 3 & Saiful & 35.000 & \\
\hline 4 & Muqit & 30.000 & \\
\hline 5 & Sholeh & 20.000 & \\
\hline 6 & Agus & 30.000 & \\
\hline 7 & Yudi & 25.000 & \\
\hline 8 & Amantoro & 25.000 & $\begin{array}{l}\text { Tabel } 4 . \\
\text { Laporan Hasil }\end{array}$ \\
\hline 9 & Beni & 20.000 & Parkir Masjid \\
\hline \multirow[t]{5}{*}{10} & Sugeng Blak & 35.000 & Al Falah \\
\hline & Jumlah & 325.000 & \\
\hline & Jumlah keseluruhan & 475.000 & \\
\hline & Saldo & 836.000 & \\
\hline & Total & 1.311.000 & \\
\hline No & Debit & Jumlah & \\
\hline 1 & Pak Nur & 20.000 & \\
\hline 2 & Gunawan & 45.000 & \\
\hline 3 & Hisyam & 45.000 & \\
\hline 4 & Mat Luki & 30.000 & \\
\hline
\end{tabular}


Masjiduna : Jurnal Ilmiah Stidki Ar-Rahmah

Vol 2 (1) (2019) : 12-25

5 Shomad

$6 \quad$ Yuli

$7 \quad$ Pak Hendrik

Jumlah

Sepatu \& sendal

Sepeda Motor

Total
ISSN 2621-0436 (cetak)

ISSN : 2621-9964 (online)

20.000

30.000

10.000

200.000

294.000

817.000

1.311.000

Pengawasan dan pengendalian pemanfaatan dan pengalihan aset merupakan satu permasalahan yang sering menjadi hujatan. Dalam meningkatkan kinerja dalam aspek ini yang paling efektif adalah dengan mengunakan SIMA (Sistem Informasi Manajemen Aset). Melalui SIMA, transparansi kerja dalam pengawasan dan pengendalian aset ini sangat terjamin tanpa harus khawatir terhadap pengawasan dan pengendalian yang lemah. ${ }^{13}$

Dari data yang telah di dapatkan oleh peneliti dari beberapa narasumber sehingga bisa peneliti simpulkan dalam sistem pengawasan manajerial Masjid Al Falah terhadap bagian keparkiran dengan cara menyetorkan laporan dari koordinator keamanan kepada bagian keuangan Masjid Al Falah.

Setiap waktu pergantian Shift dari setiap petugas parkir melaporkan dan menyetorkan hasil pendapatan dalam satu Shift tersebut kepada bagian koordinator keamanan Masjid Al Falah. Setelah koordinator keamanan menerima laporan kemudian koordinator keamanan merekap hasil laporan dari setiap petugas parkir tersebut. Setelah rekapan selesai koordinator menjumlah hasil dari seluruh pendapatan dari petugas parkir. Setelah semua terjumlah maka koordinator keamanan melaporkan dan menyetorkan hasil pendapatan dari parkir kepada bagian keuangan Masjid Al Falah setiap 2 hari sekali di hari senin, rabu dan jum'at. Laporan di lakukan secara tertulis kepada pihak keuangan Masjid Al Falah dengan rincian hasil dari pendapatan parkir mobil, motor dan infaq penitipan sandal.

\section{SIMPULAN}

Dalam pengelolaan parkir pengurus takmir Masjid Al Falah bekerjasama dengan beberapa pihak. Pertama, dinas perhubungan selaku pemilik lahan jalan dan bahu jalan. Kedua, Masjid Al Falah bekerjasama dengan warga sekitar masjid sebagai petugas parkir yang berjaga setiap harinya. Ketiga, Masjid Al Falah bekerjasama dengan warga yang mempunyai lahan kosong.

Pengurus takmir dalam penilaian kinerja atau pendapatan parkir menggunakan target capaian per tiga bulan. Pengoptimalisasian parkir Masjid Al Falah dilakukan dengan sistem satu koordinator sebagai kontrol kinerja petugas dilapangan selama proses pengelolaan parkir berlangsung. Pengawasan secara manajerial Masjid Al Falah dengan cara membuat laporan pendapatan dari koordinator kemanan untuk bagian keuangan Masjid Al Falah.

Parkir adalah suatu hal yang krusial dan dapat menimbulkan masalah besar apabila tidak dikelolah dengan baik dan benar. Namun parkir dapat menjadi aset yang bernilai dan menguntukkan berbagai pihak jika dikelolah dengan baik.

\footnotetext{
${ }^{13}$ Doli D. Siregar, manajemen aset (Jakarta : PT. Kresna Prima Persada, 2017), hal 517-520
} 


\section{DAFTAR PUSTAKA}

Al-Qur'an, 2010 (Bandung: CV penerbit Diponegoro)

Anatan, lina dan Ellitan, Lena, 2018 Supply Chain Management Perencanaan, Proses, dan Kemitraan (bandung: Alfabeta)

Asep, U. I. \& Castrawijaya, C. 2010 Manajemen Masjid (Bandung: ANGKASA)

Athoillah, Anton. 2010 Dasar-dasar Manajemen (Bandung: CV Pustaka Setia)

Daryanto \& Abdullah, 2013 Pengantar Ilmu Manajemen Dan Komunikasi (Jakarta: PT. Prestasi Pustakaraya)

Departemen Perhubungan Direktur Jendral Perhubugan Darat, Pedoman Teknis Penyelenggaraan Fasilitas Parkir

Mukhtar, 2013 Metode Praktis Penelitian Deskriptif Kualitatif (Jakarta Selatan: REFERENSI (GP Press Group))

Nugroho. A. 2018. Studi Metode Dakwah Ceramah persuasif yang Digunakan Ustadz Jamil di Masjid At-Tauhid Betiting Surabaya Pada Pengajian Kiab Al-Wajiz fi Fiqh Sunnah. Masjiduna: Jurnal Ilmiah Stidki Ar-Rahmah.Vol 1 (1) : 1-16.

Siregar, Doli D., 2017 Manajemen Aset (Jakarta: PT. Kresna Prima Persada)

Sugiyono, 2016 Memahami Penelitian Kualitatif, (Bandung: ALFABETA)

Suherman, E. 2012 Manajemen Masjid (Bandung: ALFABETA)

Tim FOKKUS BABINROHIS PUSAT \& ICMI ORSAT CEMPAKA PUTIH \& YAYASAN KADO ANAK MUSLIM, Pedoman Manajemen Masjid

Tim Yayasan Masjid Al-Falah, 35 Tahun Yayasan Masjid Al-Falah Surabaya 